\title{
Water relations, photosynthetic capacity, and growth in passion fruit (Passiflora edulis Sims f. flavicarpa Deg.): seedlings and grafted plants ${ }^{1}$
}

\author{
Mara de Menezes de Assis Gomes², Maria José Mota Ramos, Alena Torres Netto4, \\ Raul Castro Carriello Rosa $a^{5}$ Eliemar Campostrini ${ }^{2}$
}

10.1590/0034-737X201865020004

\begin{abstract}
Grafting has been used in passion fruit as a promising strategy for the improvement of traditional cultivars, which have roots susceptible to several soil pathogens. However, the effect of grafting on gas exchange, water relations, and photochemical efficiency in passion fruit is still not understood. The objective of this study was to evaluate the photosynthetic capacity, water relations, and the growth of seed-propagated (PPS) and grafted (PPG) passion fruit under drought stress. Ungrafted seedlings of Passiflora edulis f. flavicarpa and seedlings of Passiflora edulis f. flavicarpa (scion) grafted onto Passiflora mucronata (rootstock) were cultivated in a greenhouse in $3.5-\mathrm{dm}^{3}$ pots. At 37 days after transplanting (DAT), one-half of the seed-propagated plants had the watering suspended (PPSDS, plant propagated by seed under drought stress) as well as one-half of the grafted plants (PPGDS, plant propagated by grafting under drought stress). Another group of plants was kept in soil at field capacity. Gas exchanges, chlorophyll fluorescence emission, chlorophyll content, and leaf and soil water potentials were determined during the experiment. Drought-stressed plants (PPSDS and PPGDS) reduced the stomatal conductance, incident quantum yield $\left(\Phi_{\mathrm{i}}\right)$, and root dry mass in relation to the respective watered controls (PPS and PPG). Up to -50 kPa of soil water potential, both PPSDS and PPGDS reduced the photosynthetic rate by $50 \%$, without reducing leaf water potential. The seed-propagated plants showed higher growth characteristics than the grafted plants in both conditions, at the field capacity and in the substrate with water limitation. Grafting showed no effect on water status, fluorescence emission, and gas exchange.
\end{abstract}

Keywords: stomatal conductance; water stress; fluorescence; photosynthesis; leaf water potential; transpiration.

\section{RESUMO}

\section{Relações hídricas, metabolismo fotossintético e medidas biométricas em plantas de maracujazeiros (Passiflora edulis Sims f. flavicarpa Deg.): plantas seminais e plantas enxertadas}

A utilização da técnica de enxertia em maracujazeiros tem sido uma estratégia promissora para o desenvolvimento de cultivares tradicionais de maracujazeiros que, por sua vez, apresentam raízes suscetíveis a vários patógenos do solo. Contudo, não se conhece o efeito desta técnica sobre as trocas gasosas, as relações hídricas e a eficiência fotoquímica em plantas desta espécie. O objetivo deste trabalho foi estudar a capacidade fotossintética, as relações hídricas e o crescimento de maracujazeiros propagados por semente (PPS) e propagados por enxertia (PPG), submetidos à limitação da disponibilidade de água no solo. O presente estudo foi realizado em casa de vegetação, utilizando mudas de Passiflora edulis f. flavicarpa e mudas enxertadas [Passiflora edulis f. flavicarpa (enxerto) e Passiflora mucronata (porta-enxerto)] cultivadas em potes de $3,5 \mathrm{dm}^{3}$. Aos 37 dias após o transplantio (DAT), foi suspensa a

\footnotetext{
Submitted on November $10^{\text {th }}, 2016$ and accepted on November $28^{\text {th }}, 2017$.

This work is part of the practice of the subject Plant Ecophysiology (Post-Graduation Program in Plant Production / UENF).

${ }^{2}$ Universidade Estadual do Norte Fluminense, Setor de Fisiologia Vegetal, Campos dos Goytacazes, Rio de Janeiro, Brazil. mara.assis.gomes@gmail.com; campostenator@gmail.com

${ }^{3}$ Empresa Matogrossense de Pesquisa, Assistência e Extensão Rural, Cuiabá, Mato Grosso, Brazil. majumocchia@gmail.com

${ }^{4}$ Universidade Estácio de Sá, Macaé, Rio de Janeiro, Brazil. alenanetto@msn.com

${ }_{5}^{5}$ Empresa Brasileira de Pesquisa Agropecuária, Cento Nacional de Pesquisa de Agrobiologia, Seropédica, Rio de Janeiro, Brazil. raul.rosa@embrapa.br

* Corresponding author: mara.assis.gomes@gmail.com
} 
irrigação em metade das plantas propagadas por sementes (PPSDS, plantas propagadas por sementes em condições de deficiência hídrica) e em metade das plantas propagadas por enxertia (PPGDS, plantas propagadas por enxertia em condições de deficiência hídrica). Em um outro grupo de plantas, o solo foi mantido na capacidade de campo. As trocas gasosas, a emissão da fluorescência da clorofila, a estimativa do teor de clorofilas e os potenciais hídricos foliar e do solo foram determinadas durante o experimento. Nas plantas PPSDS e PPGDS, a restrição hídrica reduziu os valores da condutância estomática, o rendimento quântico incidente $\left(\Phi_{\mathrm{i}}\right)$ e a massa seca da raiz em relação aos respectivos controles mantidos irrigados (PPS e PPG). Tanto para as PPSDS e PPGDS, até os valores de $-50 \mathrm{kPa}$ de potencial hídrico do solo, houve redução da taxa fotossintética em 50\%, sem haver redução do potencial hídrico foliar. Em relação às plantas enxertadas, as plantas propagadas por semente apresentaram maiores valores das medidas biométricas, tanto cultivadas na condição de capacidade de campo, como cultivadas na condição de limitação de água no substrato. A técnica de enxertia não comprometeu o estado hídrico, a emissão da fluorescência e as trocas gasosas.

Palavras-chave: condutância estomática; estresse hídrico; fluorescência; fotossíntese; potencial hídrico foliar; transpiração.

Symbols: A, net photosynthetic rate; $g_{s}$, stomatal conductance; E, instant transpiration; VPD air, vapor pressure deficit in the air; WUE, water use efficiency $(A / E)$; IWUE, intrinsic water use efficiency $(A / g)$, PPFD, photosynthetic photon flux density, $F / F$, maximum photochemical efficiency of photosystem II, qP, photochemical quenching, qNP and NPQ, non-photochemical quenchings; $F_{m}$, maximum fluorescence, $F_{0}$, initial fluorescence; PCM, portable chlorophyll meter; PSII, photosystem II; $\Psi_{\text {soip }}$ soil water potential; $\Psi_{\text {leap }}$ leaf water potential.

\section{INTRODUCTION}

Brazil is the world's largest producer of yellow passion fruit, with an approximate production of 776,000 tons in approximately 58,000 ha (Agrianual, 2015). The states of Bahia, Ceará, Espírito Santo, and Minas Gerais are the main producers in the country. However, the expansion of the passion fruit cultivation area has been followed by the onset and aggravation of various diseases (Fischer $e t$ $a l ., 2005)$. One of the main diseases affecting yellow passion fruit is the collar rot caused by the fungus Fusarium solani (Fischer \& Rezende, 2008). This disease has already been reported in Passiflora edulis, P. edulis $\mathrm{f}$. flavicarpa, $P$. alata, P. ligularis, $P$. maliformis, and $P$. quadrangularis (Fischer \& Rezende, 2008), causing a decrease in yield and the continuous migration of the crop to pathogen-free regions (Bueno et al., 2014).

The main control practices are preventive and have not been effective in eliminating the pathogen once it is already in the soil (Roncatto et al., 2004). Thus, the use of resistant rootstocks can be an interesting alternative for the disease control (Silva et al., 2013; Santos et al., 2004).

Production of passion fruit seedlings by grafting onto rooted soft cuttings is technically feasible (Cavichioli et al., 2010, Corrêa et al., 2010; Chaves et al. al., 2004). Therefore, this technique can be used to produce seedlings for commercial crops. In São Francisco do Itabapoana, RJ, farmers have been using Passiflora mucronata as rootstock to reduce the effects of soil diseases on yield of passion fruit. The results of the introduction of rustic rootstocks such as $P$. mucronata are positive since the graft has no effect on fruit commercial quality (Salazar $e t$ al., 2016).

Drought stress is one of the environmental factors that can affect the growth and development of passion fruit (Menzel et al., 1986; Staveley \& Wolstenholme, 1990; Menzel \& Simpson, 1994). In plants of the hybrid E-23 (purple passion fruit $\mathrm{x}$ yellow passion fruit, both P. edulis Sims) grafted onto $P$. edulis flavicarpa, the net photosynthetic rate decreased at leaf water potentials $\left(\Psi_{\text {leaf }}\right)$ below -1.5 MPa (Menzel \& Simpson, 1994). According to the authors, water restriction may decrease passion fruit production due to leaf area reduction and floral bud initiation. The growth of new leaves reduced at $\Psi_{\text {leaf }}$ below $-1.5 \mathrm{MPa}$ and leaves dropped at $\Psi_{\text {leaf }}=-2.0 \mathrm{MPa}$ (Menzel \& Simpson, 1994). Menzel et al. (1986) discussed that drought stress influences the development of nodes in passion fruit and, consequently, affects its yield. Staveley \& Wolstenholme (1990) pointed out that drought stress considered moderate ( $\Psi_{\text {soil }}=-0.2$ to $-0.5 \mathrm{MPa}$ ) in the critical phenological states of the species may cause severe yield reduction.

There is no information about the differences in water relations between seed-propagated plants and grafted plants in passion fruit. Most studies have focused on the comparison of efficiency in water relations between rootstocks that have different effects on grafts (Cohen \& Naor, 2002; Clearwater et al., 2004). In coffee grown in field conditions, Fahl et al. (2001) found that, under soil drought stress (dry period), the Coffea arabica grafted 
onto Coffea canephora had higher transpiration, higher stomatal conductance, and higher growth than ungrafted coffee. The authors suggested that, during the dry period, the best performance of the grafted plants was due to a greater capacity of the root of the rootstock (Coffea canephora) in supplying water to the shoots, thus optimizing the gas exchanges and increasing the photosynthetic assimilation of carbon.

In passion fruit, few studies (Menzel et al., 1986) are related to the effects of soil water limitation on growth and photosynthetic processes between seed-propagated plants and grafted plants. Gama et al. (2013) studied the photosynthetic metabolism in five genotypes of $P$. edulis Sims f. flavicarpa in the field. They found that photosynthesis, chlorophyll fluorescence, and photosynthetic pigment content can be used as reliable markers for genetic improvement.

Thus, this study aimed to assess the photosynthesis and water relations of seedlings propagated by seed (PPS) and seedlings propagated by grafting (PPG) under drought stress.

\section{MATERIALAND METHODS}

The experiment was carried out in a greenhouse at the State University of Norte Fluminense (UENF), Campos

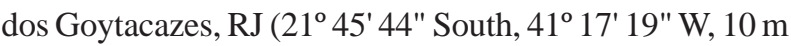
altitude), with $30 \%$ photosynthetic photon flux interception. The average temperature, vapor pressure deficit (VPD), and relative air humidity within the greenhouse during the experimental period were $26.2^{\circ} \mathrm{C}$ $\left( \pm 1.20{ }^{\circ} \mathrm{C}\right), 0.46 \mathrm{kPa}( \pm .50 \mathrm{kPa})$ and $88.6 \%( \pm 3.44 \%)$, respectively. The average soil temperature was $25.1{ }^{\circ} \mathrm{C}$ $\left( \pm 2.51{ }^{\circ} \mathrm{C}\right)$. These climatic variables were obtained by WatchDog data logger sensors, Model 450, Spectrum Technologies, USA.

The VPD ${ }_{\text {air }}$ was calculated by the equation proposed by Jones (1992):

DPVar $=0,61137 . \exp \left[\frac{(17,502 . T)}{(240,97)+T)}\right] *\left[1,0-\left(\frac{R H \%}{100}\right)\right]$

where $\mathrm{T}$ is the air temperature $\left({ }^{\circ} \mathrm{C}\right)$ and $\mathrm{RH}$ is the relative humidity $(\%)$.

The experiment was arranged in a completely randomized design with four treatments and four replications (two plants per replicate): PPS - plants propagated by seed (Control); PPG - plants propagated by grafting; PPSDS, plants propagated by seed under drought stress and PPGDS, plants propagated by grafting under drought stress.

Seedlings of Passiflora edulis f. flavicarpa provided by EMATER-RJ (São Francisco de Itabapoana, RJ) were produced in plastic tubes containing the substrate Plantmax ${ }^{\circledR}$. The seedlings were transferred to $3 \mathrm{dm}^{3}$ pots filled with Red Yellow Podzolic soil fertilized with $3.0 \mathrm{~g}$ of NPK (4-14-8) per $\mathrm{dm}^{3}$ of soil. At the time of transplanting, the seed-propagated seedlings had in average $27.5 \mathrm{~cm}$ height (approximately sixty days after sowing) and grafted plants had $26.5 \mathrm{~cm}$ (approximately sixty days after grafting). Passiflora mucronata was used as rootstock, using fullrift cleft grafting at 45 days after sowing, in which two rootstocks were used for each graft. The seedlings were kept with the same management and in the same conditions in the greenhouse after transplanting.

Soil water potential was monitored by Watermark sensors (Spectrum Technologies, USA) placed at $15 \mathrm{~cm}$ in depth and $5 \mathrm{~cm}$ distant from the plant. Each sensor was installed in one of the two plants that formed each repetition in the treatment, that is, four sensors were used for each treatment.

After transplanting, the plants were conducted on espalier system and watered daily with a watering can until percolation was observed at the bottom of each pot. At 23 and 30 days after transplanting (DAT), 1.0 and $0.5 \mathrm{~g}$ of calcium nitrate was applied in top dressing on each pot, respectively. At 37 DAT, the group of PPSDS and PPGDS plants were subjected to drought stress. The plants were not watered for seven consecutive days and the watering was resumed at 43 DAT.

Between 38 and 42 DAT, net photosynthetic rate $(A)$ $\left(\mu \mathrm{mol} \mathrm{CO} \mathrm{m}^{-2} \mathrm{~s}^{-1}\right)$, stomatal conductance $\left(\mathrm{g}_{\mathrm{s}}\right)\left(\mathrm{mol} \mathrm{m}^{-2} \mathrm{~s}^{-1}\right)$, photosynthetic photon flux density (PPFD), and transpiration $(E)\left(\mathrm{mmol} \mathrm{m}^{-2} \mathrm{~s}^{-1}\right)$ were determined using the portable gas exchange system (LI-6200, Licor, Inc., USA). The evaluations were performed with the natural incident light on the sampled leaf area $\left(6 \mathrm{~cm}^{2}\right)$ in the apparatus chamber. Then, it was possible to measure the photosynthetic rates in different light intensities, as it varies throughout the day, which allowed us to plot the rate photosynthesis against light intensity.

Leaf water potential $\left(\Psi_{\text {leaf }}\right)$ was determined at 7:00 p.m., using a pressure pump (ELLE International, England) (Scholander et al., 1965) on the leaf opposite to the one used to measure the gas exchange and while the gas exchanges were determined. Along with the measurements of leaf water potential, the intensity of leaf greenness was determined with a portable chlorophyll meter (PCM), SPAD502 (Minolta, Japan). The fluorescence variables $\left[\mathrm{F}_{0}\right.$ (initial fluorescence), $F_{m}$ (maximum fluorescence), $F_{v} / F_{m}$ (maximum PSII quantum yield), qN, qP and NPQ were determined using the Mini-PAM Walz fluorometer. The quantum yield was evaluated by the slope in the photosynthesis curve against the photosynthetic photon flux. Prior to the determination of the fluorescence variables, the area in which the fluorescence was 
determined was kept in the dark for 30 minutes, so that all photosystems were open (oxidized). The coefficients related to quenchings were defined as $\mathrm{q}_{\mathrm{p}}=\left(\mathrm{F}_{\mathrm{m}},-\mathrm{F}\right) /\left(\mathrm{F}_{\mathrm{m}}\right.$,$\left.\mathrm{F}_{0}\right), \mathrm{q}_{\mathrm{N}}=\left(\mathrm{F}_{\mathrm{m}}-\mathrm{F}_{\mathrm{m}}\right) /\left(\mathrm{F}_{\mathrm{m}}-\mathrm{F}_{0}\right)$, and $\mathrm{NPQ}=\left(\mathrm{F}_{\mathrm{m}}-\mathrm{F}_{\mathrm{m}}\right) / \mathrm{F}_{\mathrm{m}},($ Schreiber etal., 1994).

The evaluation of photosynthesis and chlorophyll fluorescence were performed on the first fully expanded leaf ( $4^{\text {th }}$ or $5^{\text {th }}$ leaf from the apex of the main branch), between $8.00 \mathrm{a} . \mathrm{m}$. and 10:00 am. At the end of the experiment (49 DAT), growth characteristics such as leaf area, leaf dry mass, stem dry mass, and root dry mass were determined. The total leaf area of the plant was determined using the LI-3100 leaf area meter, Li-Cor, USA. The root, stem, and leaf dry mass were determined by drying the material in an air circulation oven $\left(48\right.$ hours, $80^{\circ} \mathrm{C}$ ) and then weighing it.

The statistical analysis of the data was performed using the ANOVA procedure of the program SAEG, and means were compared by the Tukey's test (1\%) (Ribeiro Junior, 2001).

\section{RESULTS AND DISCUSSION}

Six days after the suspension of watering, the decrease in soil water availability caused a reduction in soil water potential $\left(\Psi_{\text {soil }}\right)$, leaf water potential $\left(\Psi_{\text {leaf }}\right)$, and plant photosynthetic rate $(A)$ of seed-propagated and grafted plants. The lowest values of $\Psi_{\text {soil }}$ (approx. -80kPa) were obtained on the last day of water restriction (42 DAT) (Figure 1), which corresponded to the lower values of leaf water potential $\Psi_{\text {leaf }}$ [approx. -2.2 MPa for PPS and 2.0 MPa for PPG] (Figure 2).
In both treatments under drought stress (PPSDS and PPGDS), the reduced values of $\Psi_{\text {soil }}$ (approximately - 60 $\mathrm{kPa}$ for grafted plants and - $80 \mathrm{kPa}$ for seed-propagated plants) corresponded to net photosynthetic rate around 2 to $4 \mu \mathrm{m} \mathrm{m}^{-2} \mathrm{~s}^{-1}$ (Figure 3 ). The substrate in the pots of PPSDS plants had greater drought stress $(-80 \mathrm{kPa})$, shown by the lower soil water potentials (Figure 1). Staveley \& Wolstenholme (1990), working with grafted passion fruit, argued that the soil water potential should not be less than $-20 \mathrm{kPa}$ during critical stages of the crop (floral differentiation and fruit fixation). Menzel \& Simpson (1994) showed that the net photosynthetic rate in grafted plants reduced at $\Psi_{\text {leaf }}$ values below -1.5 MPa.

For PPSDS and PPGDS there was a marked reduction in $\Psi_{\text {leaf }}$ from $\Psi_{\text {soil }}=-50 \mathrm{kPa}$ (Figure 2). Up to this $\Psi_{\text {soil }}$, the net photosynthetic rate in PPSDS and PPGDS reduced in approximately $50 \%$ (Figure 3 ). This reduction was associated with stomatal closure (Figure 4), but not with the compromised photochemical efficiency of PSII (Figure 5). The effect of low soil water availability on stomatal conductance and quantum yield was similar in both treatments, PPSDS and PPGDS (Figures 4 and 5).

This result was verified for the intrinsic water use efficiency (IWUE, slope of the curve of $A$ against $\mathrm{g}_{\mathrm{s}}$ ) and for water use efficiency (WUE, slope of the curve of $A$ against $E$ ) (Figure 4). Both type of plants (PPS and PPG) showed IWUE and WUE values around $29 \mu \mathrm{mol} \mathrm{mol}^{-1}$ and $0.80 \mu \mathrm{mol} \mathrm{mmol}{ }^{-1}$, respectively (Figure 4).

The maintenance of the photochemical processes under drought stress can be confirmed by the constant values of the energy dissipators (photochemical

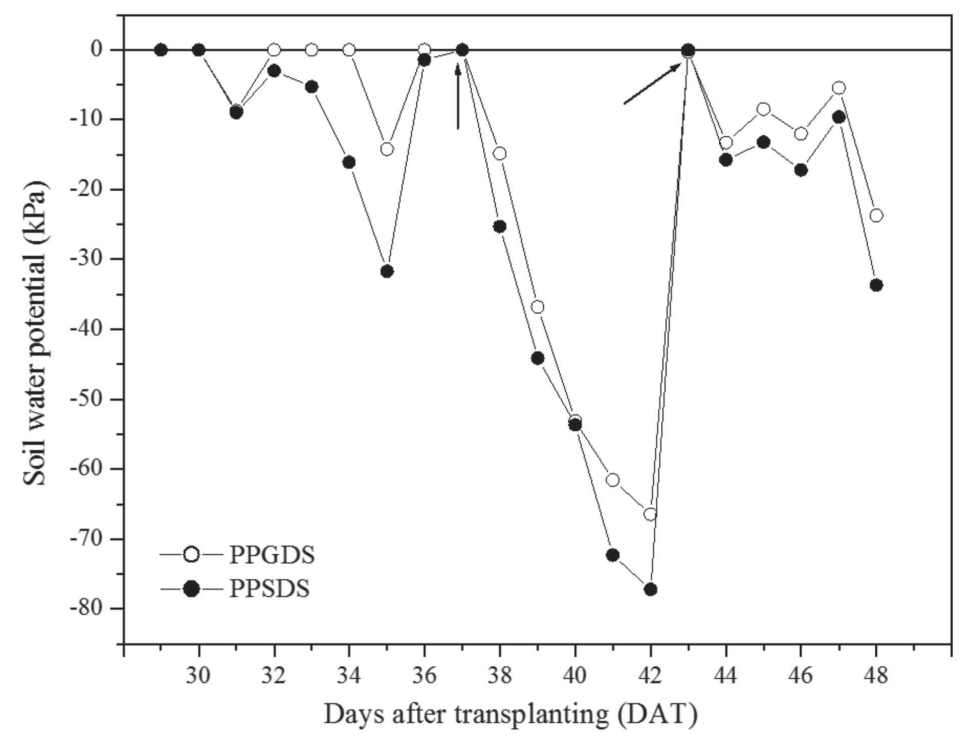

Figure 1: Soil water potential of passion fruit plants cultivation propagated by seed (PPSDS) and propagated by grafting (PPGDS) subjected to drought stress. The control plants propagated by seed and propagated by grafting had soil water potential of $0 \mathrm{kPa}$ throughout the experiment. The arrows represent the beginning of the watering suspension (37 DAT) and the start of re-watering (43 DAT), $\mathrm{n}=4$.

Rev. Ceres, Viçosa, v. 65, n.2, p. 135-143, mar/abr, 2018 


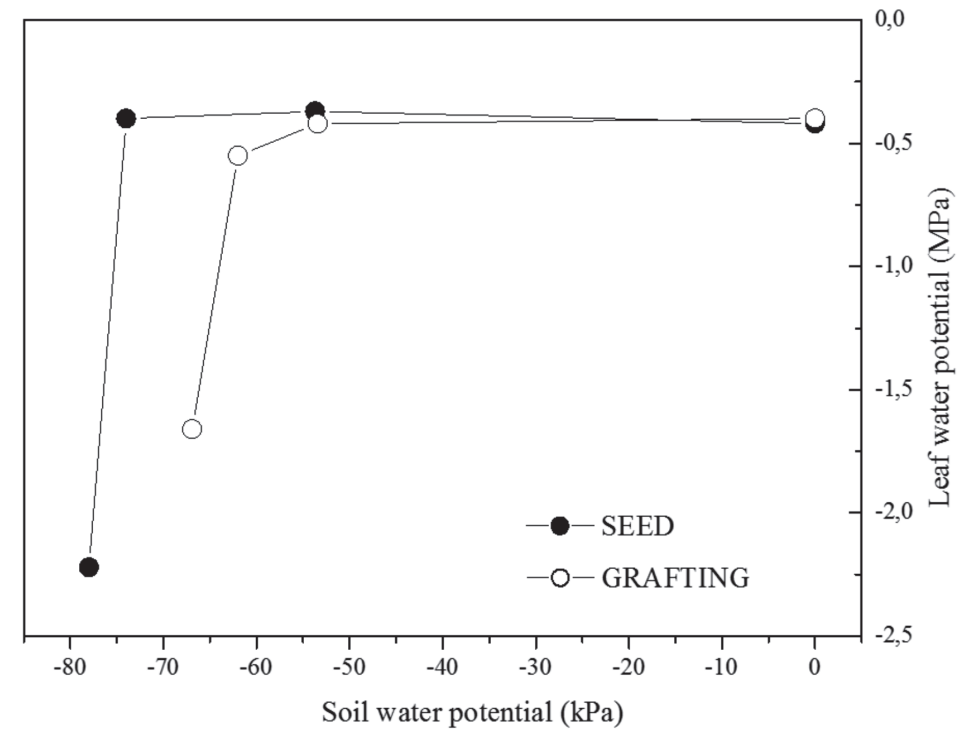

Figure 2: Relationship between soil water potential $(\mathrm{kPa})$ and leaf water potential $(\mathrm{MPa})$ of passion fruit plants propagated by seed and propagated by grafting as a function of water availability in the substrate.

quenchings (qp) and non-photochemical quenchings $\left(\mathrm{q}_{\mathrm{NP}}\right.$ and NPQ) (Figure 5). Lu \& Zhang (1999) showed that there was no effect of drought stress in the substrate on these fluorescence variables, demonstrating a nonimpairment in the re-oxidative capacity of quinone $\mathrm{A}(\mathrm{Qa})$, as well as a non-impairment in the formation of the transthylakoid proton gradient $\left(\mathrm{H}^{+}\right)$and in the xanthophyll cycle, which is represented by $\mathrm{q}_{\mathrm{P}}$ and $\mathrm{q}_{\mathrm{NP}} / \mathrm{NPQ}$, respectively.

Furthermore, the fluorescence emitted by the antenna system (F0) and the maximum fluorescence emitted showed no variation between the treatments as a function of the drought stress in the substrate (Figure 5). This finding showed a resistance of the photochemical apparatus of the passion fruit leaf tissue to drought stress. However, other authors found in P. edulis Sims., approximately 30 days after emergence, that the drought stress (suspension of watering for 11 days) affected the ratios $\mathrm{F}_{\mathrm{v}} / \mathrm{F}_{\mathrm{m}}$ and $\mathrm{ABS} / \mathrm{RC}$ (light energy absorbed per reaction center) on the day of maximum restriction. They related the reduced values of these fluorescence variables with the reduction in the activity of photosystem II (Gomes et al., 2012).

Havaux (1992) and Lu \& Zhang (1999) showed that the photosystem II (PSII) has a significant tolerance to drought stress. Havaux (1992) observed that the very strong drought stress in the leaf tissue (relative water content around $40 \%$ and leaf water potential around -4 $\mathrm{MPa}$ ) had no effect on the performance of PSII. One of the mechanisms related to the possible resistance of PSII to drought stress is the ability of oxygen to become an acceptor during the electron flow in the photochemical phase of photosynthesis (Cornic \& Briantais, 1991).
After suspending the watering, the drought stressed plants (PPSDS and PPGDS) showed no reduction in the green intensities obtained with the portable chlorophyll meter (PCM) (Figure 6). However, after re-watering the plants, all treatments showed a reduction in this value,

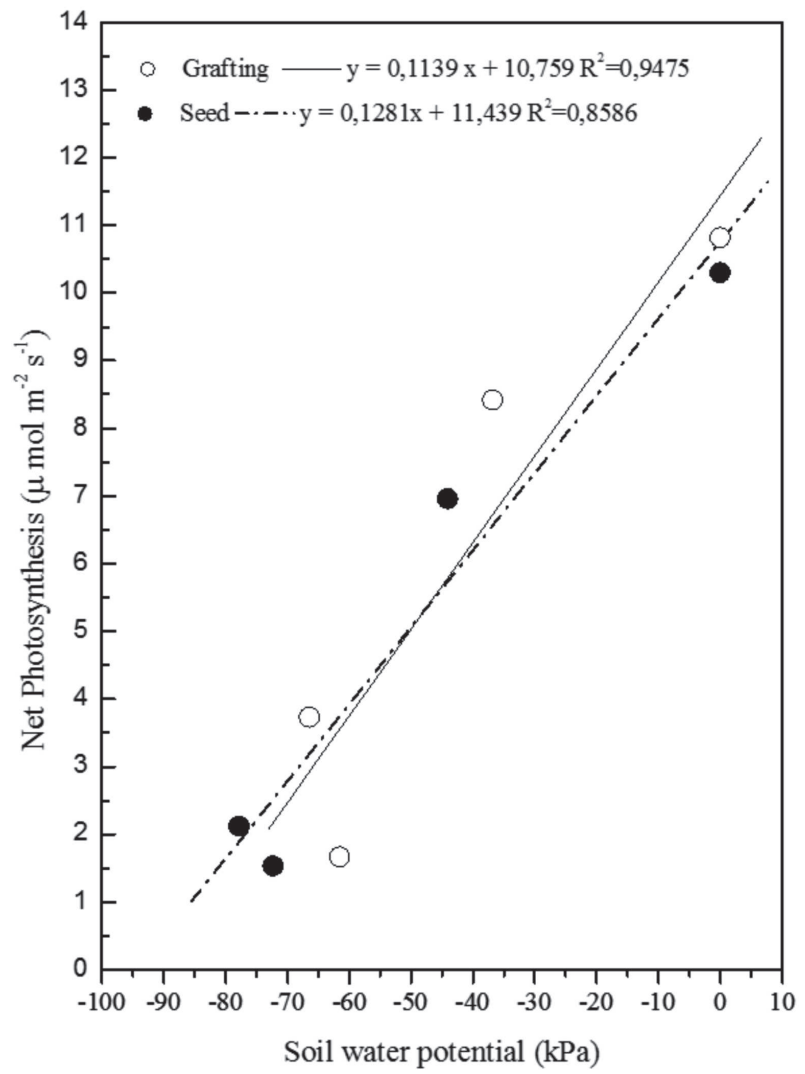

Figure 3: Relationship between net photosynthetic rate and soil water potential of passion fruit plants propagated by seed and propagated by grafting in two substrate water conditions. 
possibly related to the increase in senescence of the leaf taken for measurements. This reduction may be related to the degradation of the chlorophyll molecules in the leaf lamina, since there is a high positive correlation between nitrogen, total chlorophyll content, and PCM reading (Fox et al., 1994; Chang \& Robison, 2003, Torres-Netto et al 2005). The green intensity read by the portable chlorophyll meter (PCM) can be related to the concentration of these photosynthetic pigments in many species (Torres Netto et al., 2002 and 2005; Marquard \& Tipton, 1987; Schaper \& Chacko, 1991).
The drought stress caused no changes in the green intensity values of grafted-plants subjected to drought stress (Figure 6). According to Martinez and Guiamet (2004), the reduced relative water content in the leaf lamina causes a greater light reflectance in the cellular spaces of the cell wall-air interface. Protoplast dehydration can increase the total surface area of the cell wall-air interface, thereby increasing the reflectance in the visible region (400-700 nm). However, this effect of dehydration, causing an increase in the PCM reading was not verified in PPSDS plants.
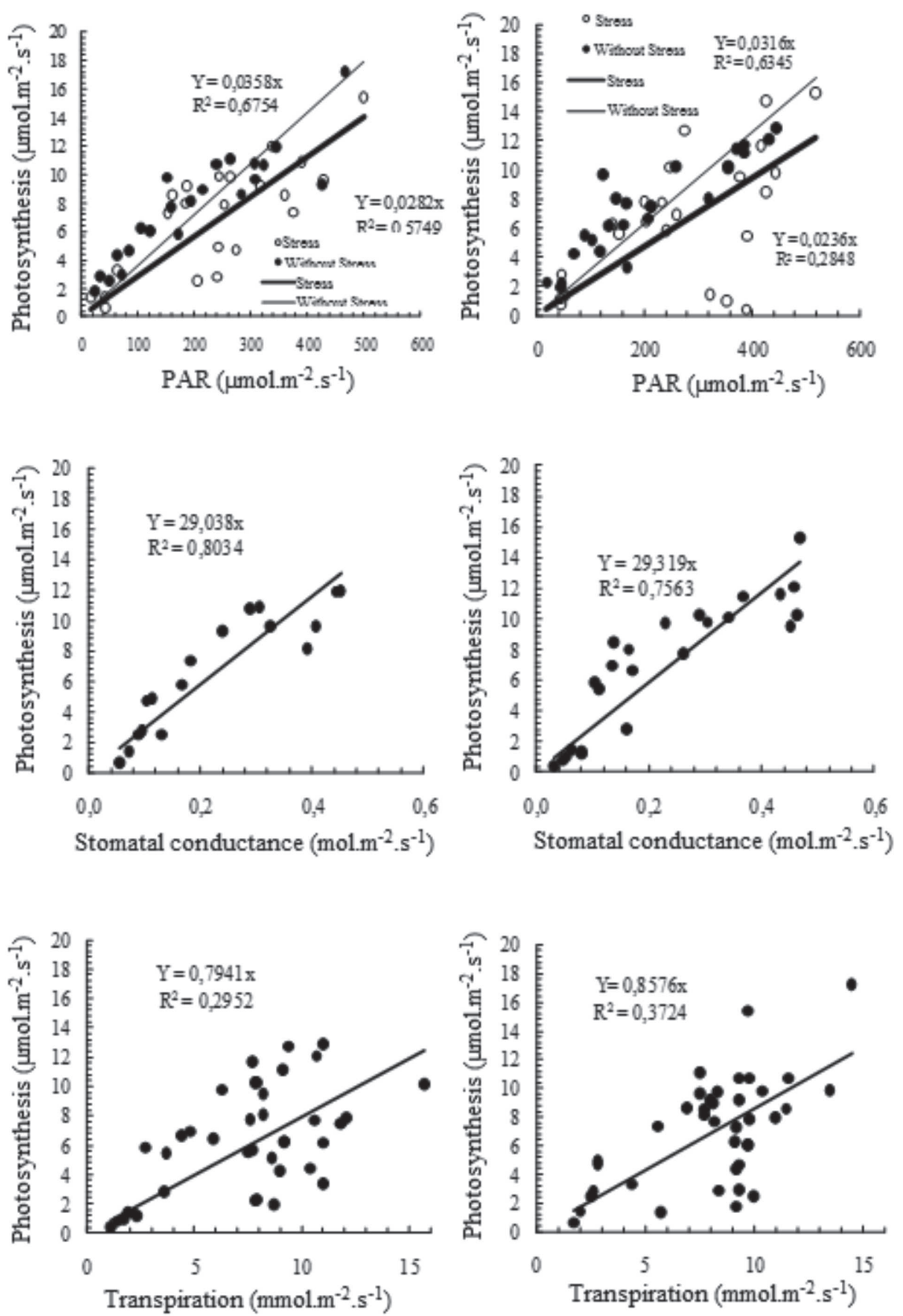

Figure 4: Relationship between net photosynthetic rate, photosynthetic photon flux density, stomatal conductance, and transpiration in passion fruit plants propagated by seed (left column) and propagated by grafting (right column) grown in two substrate water regimes (field capacity and drought stress). 

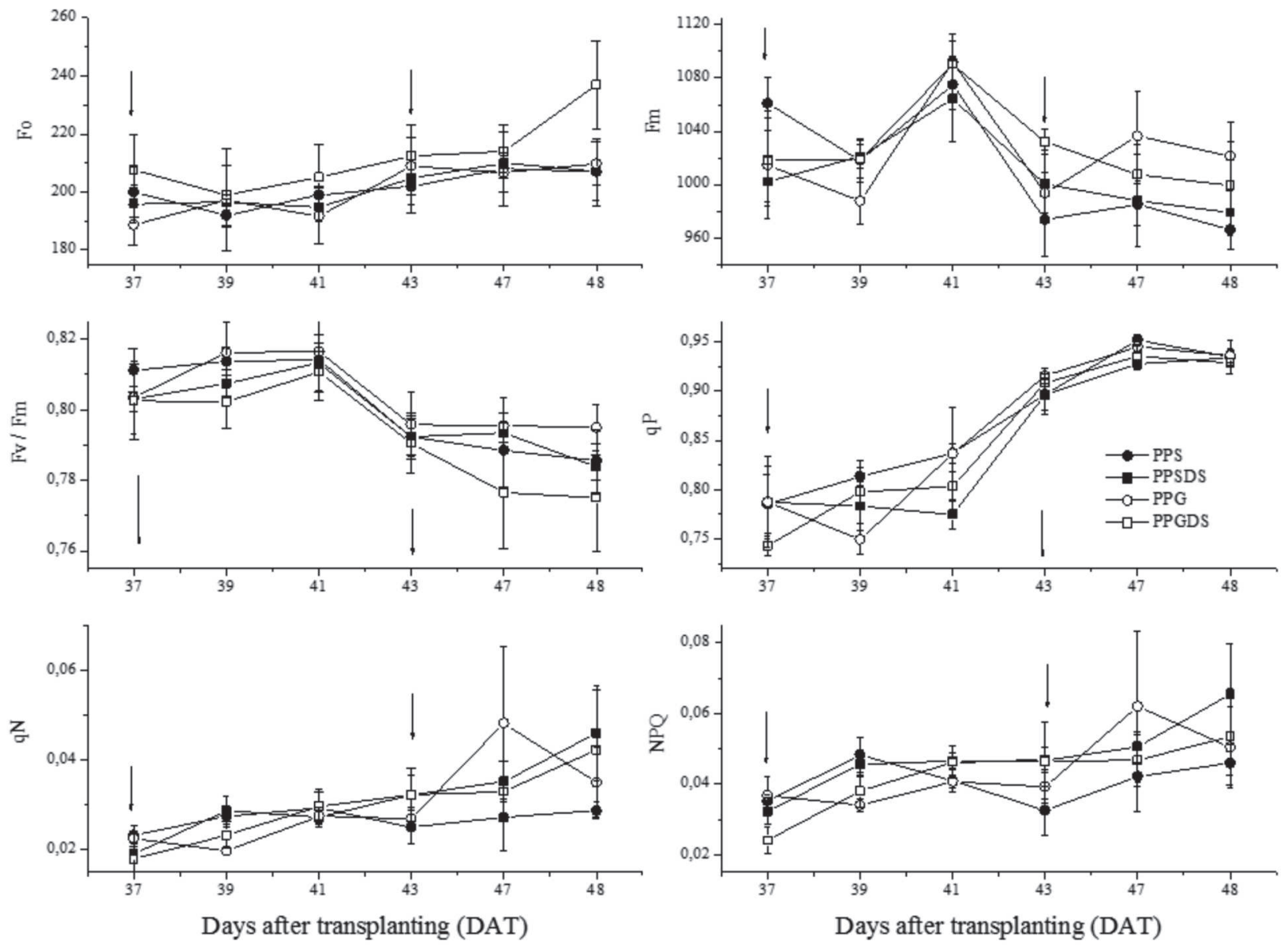

Figure 5: Variables of fluorescence in leaves of seed-propagated and grafted passion fruit plants grown in two water regimes. PPGDS (plants propagated by grafting subjected to drought stress); PPG (plants propagated by grafting grown at field capacity); PPSDS (plants propagated by seed subject to drought stress); PPS (plants propagated by seed grown at field capacity). The arrows represent the beginning of the watering suspension (37 DAT) and the start of re-watering (43 DAT). Vertical bars represent the standard error.

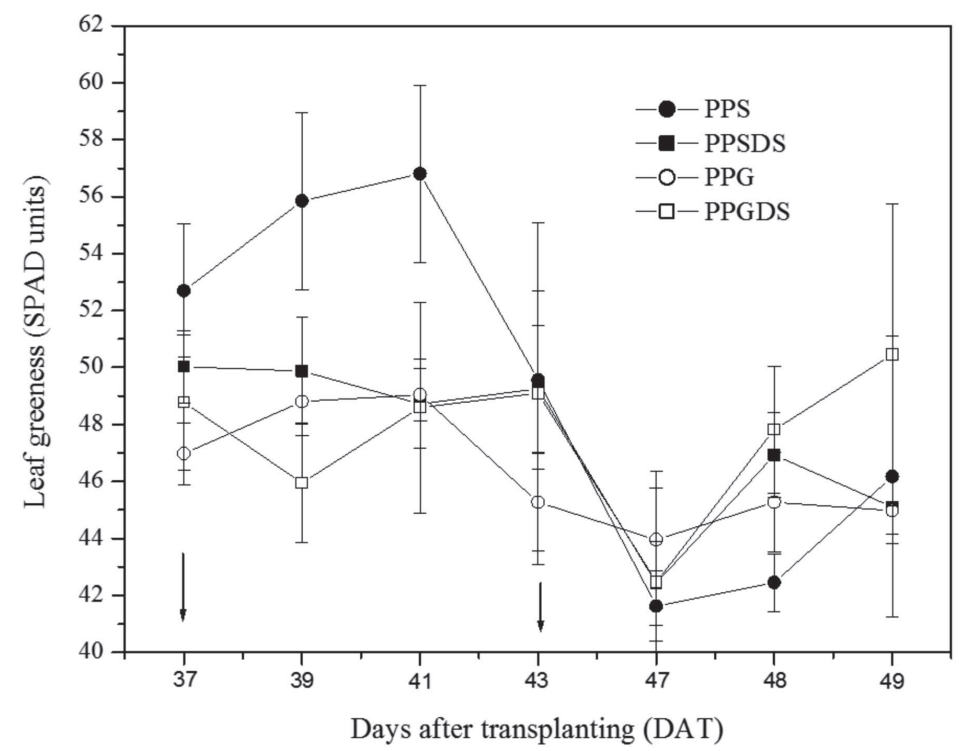

Figure 6: Readings of portable chlorophyll meter in leaves of seed-propagated and grafted passion fruit plants in two water regimes. PPGDS (plants propagated by grafting subjected to drought stress); PPG (plants propagated by grafting grown at field capacity); PPSDS (plants propagated by seed subject to drought stress); PPS (plants propagated by seed grown at field capacity). The arrows represent the beginning of the watering suspension (37 DAT) and the start of re-watering (43 DAT). Vertical bars represent the standard error. 
Table 1: Dry mass of stem, leaf, and root and leaf area of passion fruit plants propagated by seed and propagated by grafting cultivated in two water regimes. Treatments: PPGDS (plants propagated by grafting subjected to drought stress); PPG (plants propagated by grafting grown at field capacity); PPSDS (plants propagated by seed subject to drought stress); PPS (plants propagated by seed grown at field capacity)

\begin{tabular}{lccccc}
\hline \multirow{2}{*}{ Treatment } & \multicolumn{3}{c}{ Dry Mass $(\mathbf{g})$} & & Leaf Area \\
\cline { 2 - 4 } \cline { 2 - 3 } & Stem & Leaf & Root & $10.3 \mathrm{a}$ & \\
\hline PPS & $6.9 \mathrm{a}$ & $10.0 \mathrm{a}$ & $7.1 \mathrm{~b}$ & $1634.5 \mathrm{a}$ \\
PPSDS & $5.7 \mathrm{a}$ & $6.3 \mathrm{ab}$ & $7.5 \mathrm{~b}$ & $1191.2 \mathrm{~b}$ \\
PPG & $5.4 \mathrm{ab}$ & $6.3 \mathrm{ab}$ & $5.3 \mathrm{c}$ & $1237.6 \mathrm{~b}$ \\
PPGDS & $4.7 \mathrm{~b}$ & $4.7 \mathrm{~b}$ & $944.2 \mathrm{~b}$ \\
\hline
\end{tabular}

Means followed by the same letter are not significantly different by the Tukey's test at $1 \%$ probability level. Data collected at the end of the experiment.

At the end of the experiment (49 DAT), we found that the PPS plants had the highest root dry mass and the greatest leaf area than the other treatments (Table 1). drought stress in the substrate of PPSDS caused a reduction of $31 \%$ in the dry mass of root and $27 \%$ in leaf area, in relation to PPS. Drought stress in the substrate of PPGDS caused significant differences only in root dry mass, in relation to PPG.

\section{CONCLUSION}

The net photosynthetic rate was reduced in plants propagated by seed and plants propagated by grafting before the reduction in leaf water potentials.

There was no effect of the treatments on the photochemical efficiency evaluated by the fluorescence emission of chlorophyll $a$.

Grafting of passion fruit reduced root dry mass and leaf area in comparison with plants propagated by seed.

\section{REFERENCES}

Agrianual (2015) Anuário da Agricultura Brasileira. São Paulo, Instituto AgraFNP. 344p.

Bueno CJ, Fischer IH, Rosa DD, Firmino AC, Harakava R, Oliveira CMG \& Furtado EL (2014) Fusarium solani f. sp. passiflorae: a new forma specialis causing collar rot in yellow passionfruit. Plant Pathology, 63:382-389.

Cavichioli JC, Kasai FS \& Nasser MD (2014) Productivity and physical characteristics of fruits of Passiflora edulis grafted Passiflora gibertii in different planting densities. Revista Brasileira de Fruticultura, 36:243-247.

Chang SX \& Robison DJ (2003) Nondestructive and rapid estimation of hardwood foliar nitrogen status using the SPAD502 chlorophyll meter. Forest Ecology and Management, 6215:1-8.

Chaves RCC, Junqueira NTJ, Manica I, Peixoto JR, Pereira AV \& Fialho JF (2004) Enxertia em maracujazeiro-azedo em estacas herbáceas enraizadas de espécies de passifloras nativas. Revista Brasileira de Fruticultura, 26:120-123.

Clearwater MJ, Lowe RG, Hofstee BJ, Barclay C, Mandenmaker AJ \& Blattmann P (2004) Hydraulic conductance and rootstock effects in grafted vines of kiwifruit. Journal of Experimental Botany, 55:1371-1382.
Cohen S \& Naor A (2002) The effect of three rootstocks on water use, canopy conductance and hydraulic parameters of apple trees and predicting canopy from hydraulic conductance. Plant, Cell and Environment, 25:17-28.

Corrêa LS, Cavichioli JC, Oliveira JC \& Boliani AC (2010) Use of humid chamber in conventional grafting of yellow passion fruit on three rootstocks. Revista Brasileira de Fruticultura, 32:591-598.

Cornic G \& Briantais JM (1991) Partitioning of photosynthetic electron flow between $\mathrm{CO}_{2}$ and $\mathrm{O}_{2}$ reduction in a $\mathrm{C} 3$ leaf (Phaseolus vulgaris L.) at different $\mathrm{CO}_{2}$ concentrations and during drought stress. Planta, 183:178-184.

Fahl JI, Carelli MLC, Menezes HC, Gallo PB \& Trivelin PCO (2001) Gas exchange, growth, yield and beverage quality of Coffea arabica cultivars grafted on to C. canephora and $C$. congensis. Experimental Agriculture, 37:241-252.

Fischer IH, Lourenço SA, Martins MC, Kimati H \& Amorim L (2005) Seleção de plantas resistentes e de fungicidas para o controle da podridão do colo do maracujazeiro causada por Nectria hematococca. Fitopatologia Brasileira, 30:250-258.

Fischer IH \& Rezende JAM (2008) Diseases of passion flower (Passiflora spp.). Pest Technology, 2:01-19.

Fox RH, Piekielek WP \& MacNeal KM (1994) Using a chlorophyll meter to predict nitrogen fertilizer needs of winter wheat. Communication in Soil Science and Plant Analysis, 25:171-181.

Gama VN, Cunha JT, Lima IM, Bacarin MA \& Silva DM (2013) Photosynthetic characteristics and quality of five passion fruit varieties under field conditions. Acta Physiologiae Plantarum, 35:941-948

Gomes MTG, Luz AC, Santos MR, Batitucci MCP, Silva DM \& Falqueto (2012) Drought tolerance of passion fruit plants assessed by the OJIP chlorophyll a fluorescence transient. Scientia Horticulturae, 142:49-56.

Havaux M (1992) Stress tolerance of photosystem II in vivo. Plant Physiology, 100:424-432.

Jones HG (1992) Plants and microclimate: a quantitative approach to environmental plant physiology. $2^{\mathrm{a}}$ Ed. Cambridge, Cambridge University Press. 85 p.

Lu C \& Zhang J (1999) Effects of water stress on photosystem II photochemistry and its thermostability in wheat plants. Journal of Experimental Botany, 50:1199-1206.

Marquard RD \& Tipton JL (1987) Relationship between extractable chlorophyll and in situ methods to estimate leaf greenness. HortScience, 22:1327.

Martinez DE \& Guiamet JJ (2004) Distortion of the SPAD 502 chlorophyll meter readings by changes in irradiance and leaf water status. Agronomie, 24:41-46 
Menzel CM, Simpson \& Dowling AJ (1986) Water relations in passionfruit: efffect of moisture stress on growth, flowering and nutrient uptake. Scientia Horticulturae, 29:239-249.

Menzel CM \& Simpson DR (1994) Passionfruit. In: Schaffer B \& Andersen PC (Eds.) Handbook of environmental physiology of fruit crops. Boca Raton, CRC Press. p.225-241.

Ribeiro Jr. JI (2001) Análises estatísticas no SAEG. Viçosa, Universidade Federal de Viçosa. 301p.

Roncatto G, Oliveira JC, Ruggiero C, Nogueira Filho GC, Centurion MAPC \& Ferreira FR (2004) Comportamento de maracujazeiros (Passiflora spp.) quanto à morte prematura. Revista Brasileira de Fruticultura, 26:552-555.

Roncatto G, Assis GML, Oliveira TK \& Lessa LS (2011a) Vegetative features of combinations scion/rootstock in passion fruit plant. Revista Brasileira de Fruticultura, 33:791-797.

Roncatto G, Assis GML, Oliveira TK \& Lessa LS (2011b) Grafting success in diferente combinations of species and varieties used as scion and the rootstock of passion fruit plant. Revista Brasileira de Fruticultura, 33:948-953.

Salazar AH, Silva DFP \& Bruckner CH (2016) Effect of two wild rootstocks of genus Passiflora L. on the content of antioxidants and fruit quality of yellow passion fruit. Bragantia, 75:164172 .

Santos VA, Ramos JD, Chagas EA, Dias MM, Locatelli G \& Oliveira MC (2014) Grafting of different combinations of scions and rootstocks of passion fruit plants. Semina, Ciências Agrárias, 35:1201-1208.
Schaper H \& Chacko EK (1991) Relation between extractable chlorophyll and portable chlorophyll meter readings in leaves of light tropical and subtropical fruit-tree species. Journal of Plant Physiology, 138:674-677.

Scholander PF, Hammel HT, Bradstreet ED \& Hemmingsen EA (1965) Sap pressure in vascular plants. Science, 148:339-346.

Schreiber U, Bilger W \& Neubauer C (1994) Chlorophyll fluorescence as a nonintrusive indicator for rapid assessment of in vivo photosynthesis. In: Schulze E.D \& Caldwell MM (Eds.) Ecophysiology of photosynthesis. Heidelberg, Springer-Verlag. p.49-70.

Staveley GW \& Wolstenholme BN (1990) Effects of water stress on growth and flowering of Passiflora edulis (Sims) grafted to P. Caerulea L. Acta Horticulturae, 275:551-558.

Silva AS, Oliveira EJ, Haddad F, Laranjeira FF, Jesus ON, Oliveira SAS, Costa MAPC \& Freitas JXF (2013) Identification of passion fruit genotypes resistant to Fusarium oxysporum f. sp. Passiflorae. Tropical Plant Pathology, 38:236-242.

Torres Neto A, Campostrini E, Oliveira JG \& Bressan-Smith (2005) Photosynthetic pigments, nitrogen, chlorophyll $a$ fluorescence and SPAD-502 readings in Coffea leaves. Scientia Horticulturae, 104:199-209.

Torres Neto A, Campostrini E, Oliveira JG \& Yamanishi OK (2002) Portable chlorophyll meter for the quantification of photosynthetic pigments, nitrogen and the possible use for assessment of the photochemical process in Carica papaya $\mathrm{L}$. Brazilian Journal of Plant Physiology, 14:203-210. 